\title{
Implementation of Fuzzy logic control based MPPT for Photovoltaic system with Silicon Carbide (SiC) boost DC-DC converter
}

\author{
A.BHARATHI SANKAR AMMAIYAPPAN*, R.SEYEZHAI ** \\ *School of Electronics Engineering, VIT University Chennai Campus, \\ Chennai, Tamilnadu, INDIA \\ **Department of Electrical \& Electronics Engineering, \\ SSN college of Engineering Chennai, Tamilnadu, INDIA
}

Abstract: In recent days, photovoltaic (PV) system is the most promising renewable energy technologies and the PV cell has to operate at the optimum operating point to deliver maximum power. In order to obtain maximum power from PV, a maximum power point controller is required. This paper presents the simulation and hardware implementation of fuzzy logic (FL) maximum power point (MPPT) controller with FPGA technology for photovoltaic system. The MPPT algorithm is implemented for a Silicon carbide (SiC) MOSFET based boost DC-DC converter which provides fast switching, low losses and high voltage gain. The proposed MPPT algorithm is implemented on a SPARTAN/FPGA board platform based on the model developed and executed in MATLAB/SIMULINK. The entire system designed and implemented to hardware was successfully tested on a laboratory prototype PV array. The experimental results show the effectiveness and feasibility of the proposed controller and the results were satisfactory.

Keywords: Photovoltaic panel, Maximum power point tracking control, Silicon carbide, Fuzzy logic control, Field Programmable Gate Array.

Received: November 6, 2020. Revised: March 18, 2021. Accepted: April 4, 2021. Published: April 20, 2021.

\section{Introduction}

Nowadays, photovoltaic system has an increased importance in electrical power generation system, since it is an inexhaustible and broadly available energy resource. An important characteristic of photovoltaic panels is that the available maximum power is provided only in a single operating point given by a voltage and current known, called maximum power point $[1,2]$. Another drawback is that the position of maximum power point is not fixed and it moves according to the varying irradiance, the varying temperature and load. Because of the relatively expensive cost of this kind of energy we must extract the maximum of power of photovoltaic panels. This requires a mechanism for the tracking of the maximum power point called maximum power point tracking so that maximum power is generated effectively [ 3 , 4]. The schematic representation of the proposed photovoltaic power generation system is shown in Figure.1. In the literature, many classical methods and controllers have been widely developed and implemented to track the maximum power point $[5,6]$. This paper has proposed a fuzzy control with FPGA technology design and implementation for MPPT. The advantage of the fuzzy logic control is that it does not need any mathematical model of the system. In addition, it simplifies while dealing with nonlinearities in systems. Moreover, FPGA is suitable for faster implementation and control which can be programmed to do any type of required digital functions [7, 8]. It has the ability to operate faster than a microcontroller chip. Because of the flexibility in FPGA, additional functionality and user interface controls can be 
incorporated into the FPGA minimizing the requirement for additional external components $[9,10]$. Hence, fuzzy MPPT control is implemented using FPGA. The solar panel is rarely connected directly to a load, the DC-DC converter is necessary and it acts as a suitable interface between the photovoltaic panel and the load allowing to track the maximum power point based on MPPT control providing a duty cycle by exciting the boost converter's electronic switch [11, 12]. There are several DC-DC converters employed for this purpose. But, this paper presents a DC-DC boost converter based on SiC MOSFET and a fast recovery diode for freewheeling action. The proposed $\mathrm{SiC}$ based converter can operate at high switching frequency and high temperature operation. Power converters made with Silicon Carbide (SiC) devices offer higher power density due to its higher blocking voltage capability, lower on state resistance and higher thermal conductivity when compared to their conventional power electronics devices [13]. Therefore, $\mathrm{SiC}$ MOSFET is chosen for the boost converter.

This paper presents the simulation and hardware implementation of fuzzy logic controller (FLC) using FPGA for PVMPPT. A significant advantage of the proposed controller is that it has been coded in VHDL and programmed into a single FPGA [14, 15]. The performance of the fuzzy logic controller is tested for stand-alone PV system under various operational conditions, such as changing solar radiance, temperature and load. The simulations are verified with experimental results.

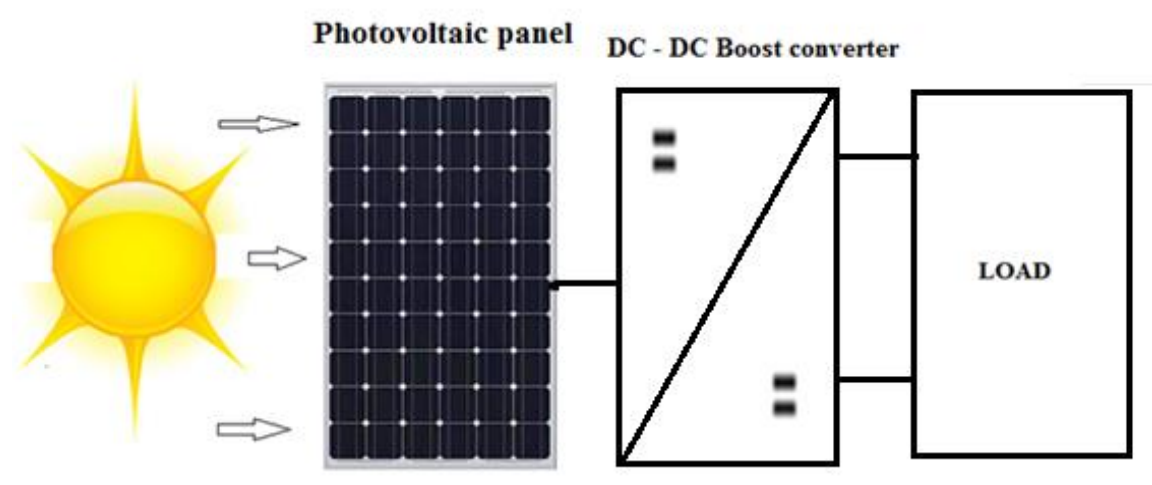

Figure 1 Schematic representation of modeled Photovoltaic power generation system 


\section{Modelling Of Solar Cell}

A solar cell is the building block of a photovoltaic panel. A photovoltaic panel is developed by connecting many solar cells in series and parallel. A single photovoltaic cell can be modeled by utilizing current source, diode and two resistors as shown in Figure 2.

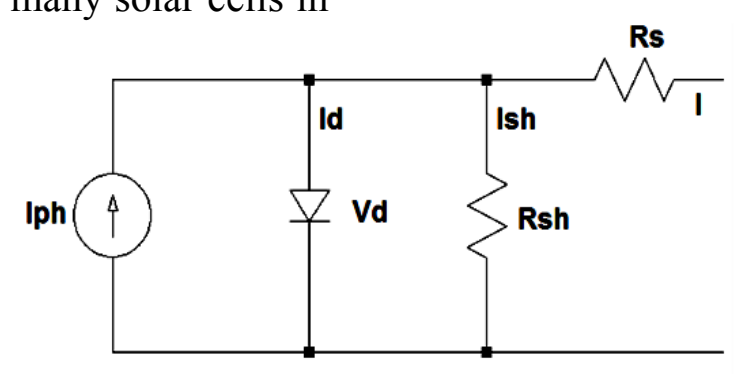

Figure 2: A single solar cell circuit model

The equation for a photovoltaic cell is given by

$$
\begin{array}{r}
I=I_{l g}-I_{o s} *\left[\exp \left\{q * \frac{V+I * R_{s}}{A * k * T}\right\}-1\right]-\frac{V+I * R_{s}}{R_{s h}} \ldots \ldots \\
I_{o s}=I_{o r} *\left(\frac{T}{T_{r}}\right)^{3} *\left[\exp \left\{q * E_{g o} * \frac{\frac{1}{T_{r}}-\frac{1}{T}}{A * k}\right\}\right] \ldots \ldots \text { (2) } \\
I_{l g}=\left\{I_{s c r}+K_{i} *(T-25)\right\} * \lambda \ldots \ldots \ldots \text { (3) } \\
I=N_{p} * I_{l g}-N_{p} * I_{o S} *\left[\exp \left\{q * \frac{\frac{V}{N_{s}}+I * \frac{R_{s}}{N_{p}}}{A * k * T}\right\}-1\right]-\frac{V *\left(\frac{N_{p}}{N_{S}}\right)+I * R_{S}}{R_{s h}}
\end{array}
$$

Where I \& V: Photovoltaic cell output current and voltage;

Ios: PV cell reverses saturation current;

T: Solar cell temperature in Celsius;

$\mathrm{k}$ : Boltzmann's constant, $1.38 * 10^{-19} \mathrm{~J} / \mathrm{K}$;

q: Electron charge, $1.6^{*} 10^{-23} \mathrm{C}$;

$\mathrm{K}_{\mathrm{i}}$ : Short circuit current temperature coefficient at $\mathrm{I}_{\text {scr }}$;

$\lambda$ : Solar cell irradiation in $\mathrm{W} / \mathrm{m}^{\wedge} 2$;

$\mathrm{I}_{\text {scr: }}$ : Short circuit current at 25 degree Celsius;

$\mathrm{I}_{\mathrm{lg}}$ : Light-generated current;

Ego: Band gap for silicon;

A: Ideality factor;

$\mathrm{T}_{\mathrm{r}}$ : Reference temperature;

Ior: Cell saturation current at Tr;

$\mathrm{R}_{\text {sh: }}$ : Shunt resistance;

$\mathrm{R}_{\mathrm{s}}$ : Series resistance; 
The P-V and V-I characteristics for a photovoltaic cell are shown in Figures. $3 \&$ 4. It can be seen that the photovoltaic cell operates as a constant current source at low values of operating voltages and a constant voltage source at low values of operating current. Electrical specifications of solar panel are: open circuit voltage: $21 \mathrm{~V}$, short circuit current: 5.5A, total no of cells in series: 36 and solar cell temperature: 30 degree Celsius. The input irradiation is shown in Figure.5. Between 0 and $1 \mathrm{~s}$, the irradiation is $200 \mathrm{~W} / \mathrm{m}^{2}$, between 1 and $2 \mathrm{~s}$ it is $600 \mathrm{~W} / \mathrm{m}^{2}$, while from $2 \mathrm{~s}$ onwards it is $1000 \mathrm{~W} / \mathrm{m}^{2}$

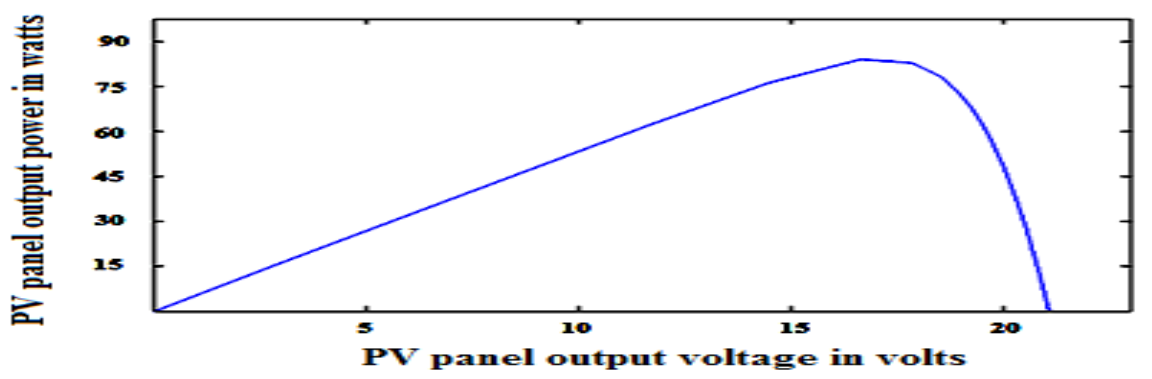

Figure 3: P-V characteristics of a solar panel

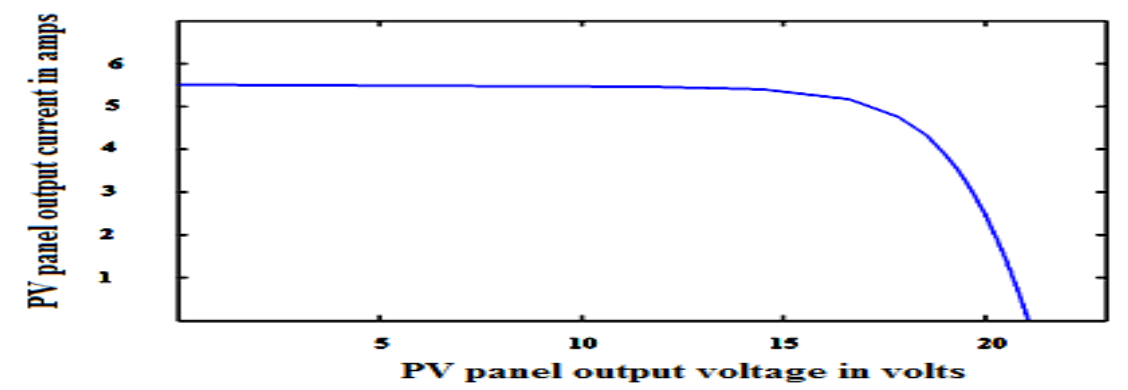

Figure 4: I-V characteristics of a solar panel

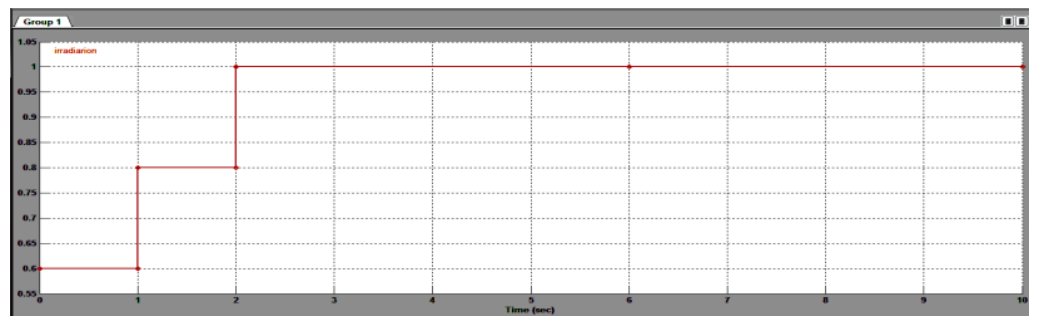

Figure.5. Input - Time varying irradiation 


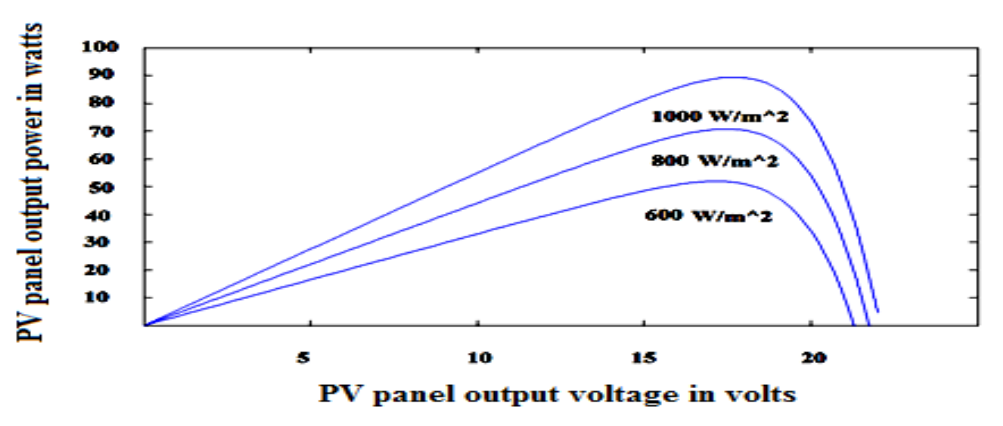

Figure. 6.P-V characteristics of a typical PV module for varying solar irradiance.

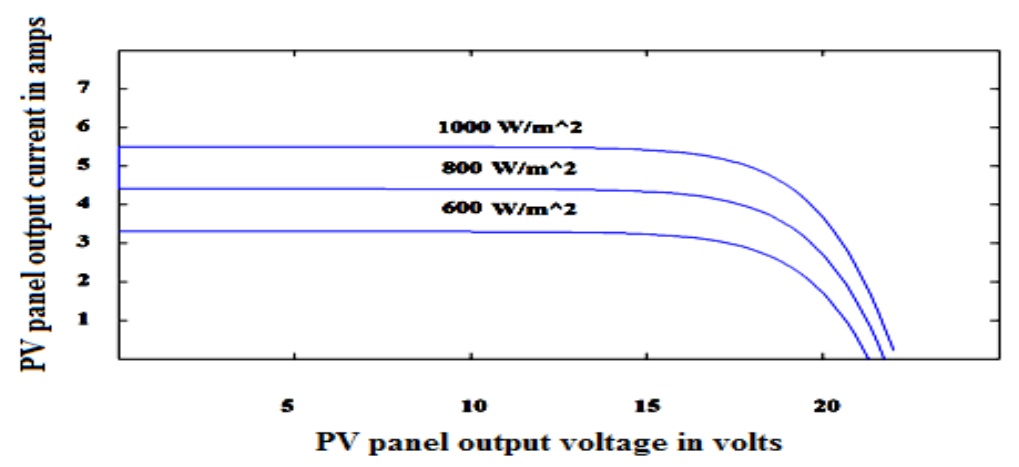

Figure. 7. I-V characteristics of a typical PV module for varying solar irradiance.

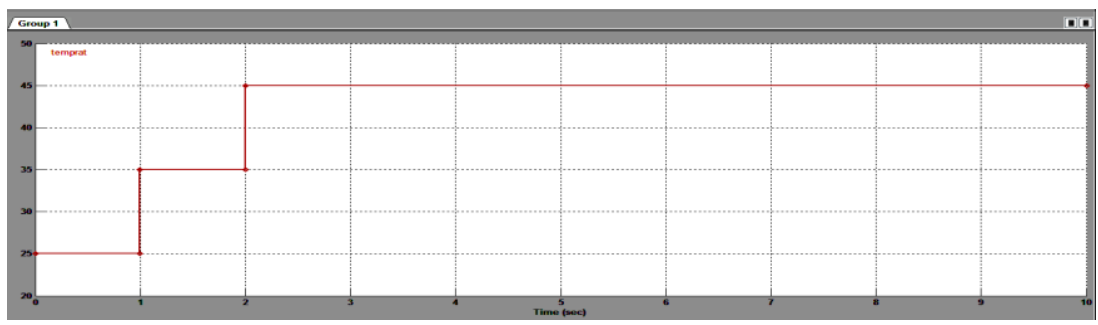

Figure.8. Input - Time varying temperature

The P-V output characteristic of PV module with varying irradiation at constant temperature is shown in Figure .6. The I-V output characteristic of PV module with varying irradiation at constant temperature is shown in Figure .7. When the irradiation increases, the current output increases and the voltage output also increases. This results in net increase in output power with increase in irradiation at constant temperature. The time varying temperature signal is shown in Figure.8. Between 0 and 1 second, the temperature of $25 \mathrm{C}$ is applied and it is increased to $35 \mathrm{C}$ and $45 \mathrm{C}$. 


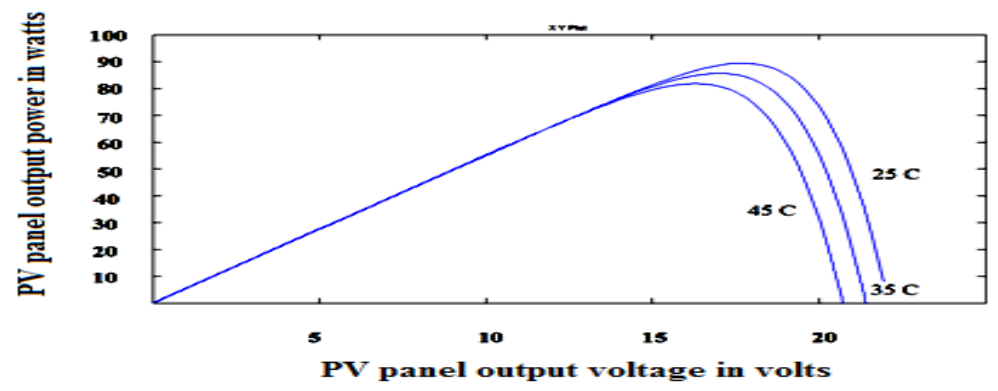

Figure. 9. P-V characteristics of a typical PV module for varying temperature

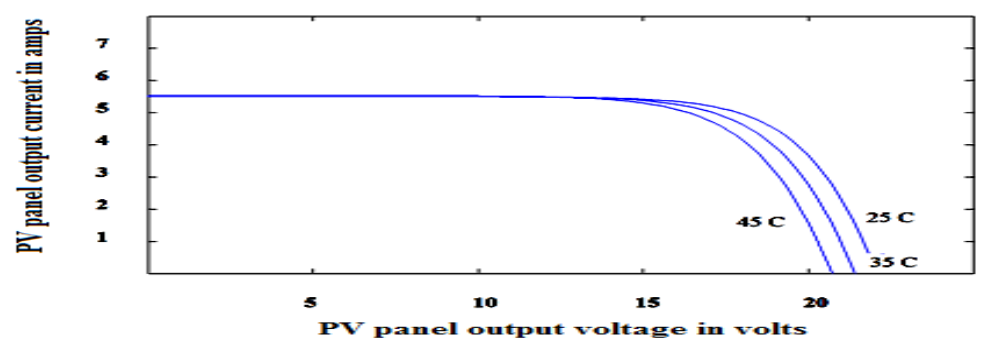

Figure.10.I-V characteristics of a typical PV module for varying temperature.

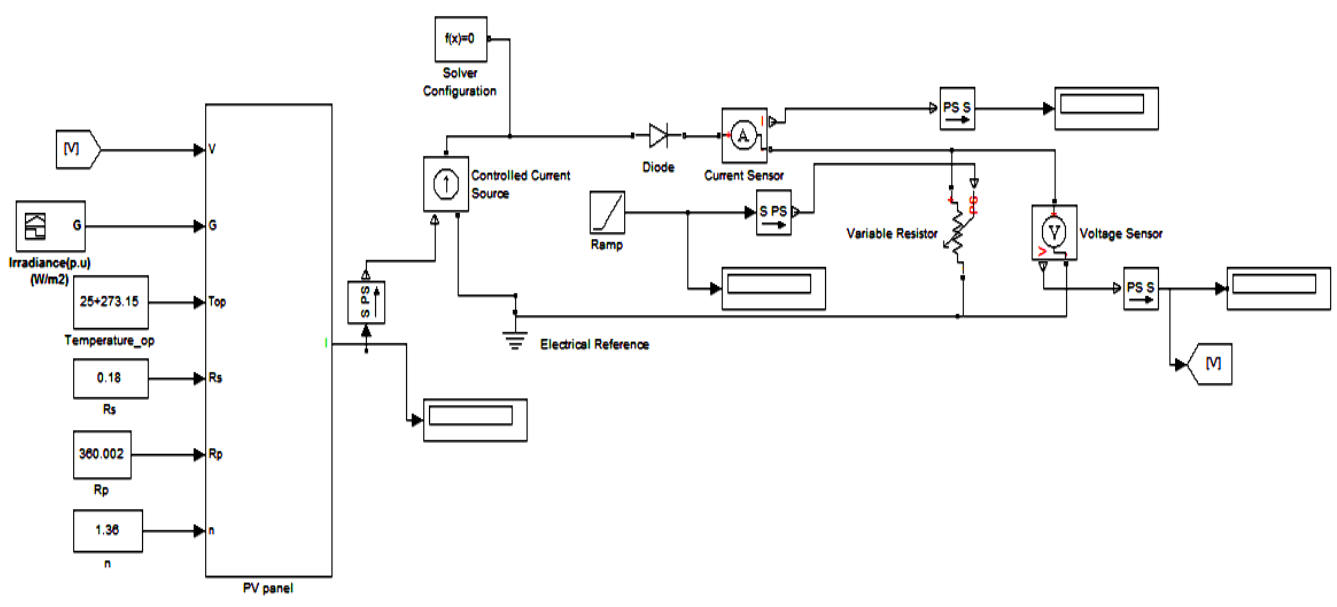

Figure 11: Simulink model of the photovoltaic panel

The P-V output characteristic of PV module with varying temperature at constant irradiation is shown in Figure.9. The I-V output characteristic of PV module with varying temperature at constant irradiation is shown in Figure .10. When the operating temperature increases, the current output increases marginally but the voltage output decreases drastically results in net reduction in power output with rise in temperature. Simulink model of the photovoltaic panel is shown in Figure.11.The photovoltaic panel voltage is about $21.75 \mathrm{~V}$ and the photovoltaic panel current is about $5.45 \mathrm{~A}$ as shown in Figure.4. Photovoltaic panel output power is about 100W is shown in Figure.3. 


\section{Maximum Power Point Tracking}

The output efficiency of a photovoltaic cell is very low. In order to increase the efficiency, different methods are analyzed to match the source and load properly. Therefore, one such method is the Maximum Power Point Tracking control technique. This technique is used to obtain the maximum possible output power from a varying source. In the photovoltaic systems, the V-I curve is non-linear, so it is difficult to get matched with the load. This technique is used for boost converter whose switching duty cycle is varied using a maximum power point tracking algorithm [16, 17]. A boost converter is used on the load side and a photovoltaic panel is used to power this converter. Various MPPT techniques are available in the literature [18, 19], but this paper focuses on fuzzy logic control based MPPT implemented using FPGA.

\subsection{Fuzzy logic control based MPPT}

Several methods of tracking the optimal point of operation have been discussed in the literature but the approach of artificial intelligence in the case of fuzzy logic is implemented to improve the controller performance and the pursuit of maximum power point by simulation and modeling of a controller based on fuzzy logic control system. Block diagram of fuzzy logic control MPPT based photovoltaic power generation system is shown in Figure.12. The fuzzy theory based on fuzzy set and fuzzy algorithm provides a general method of expressing linguistic rules so that they may be processed quickly. The advantage of the fuzzy logic control is that it does not strictly need any mathematical model of the system. Hence, many complex systems can be controlled without knowing the exact mathematical model of the system. In addition, fuzzy logic simplifies the design when dealing with nonlinearities in systems. Fuzzy controller design includes the following elements:

$>$ Determine the fuzzy controller input variables and output variables.

$>$ Design the control rules of fuzzy controller.

$>$ Establish fuzzification and Defuzzification method.

$>$ Select the domain of fuzzy controller input and output variables as well as determine the parameters.

$>$ Prepare the application of fuzzy control algorithm.

$>$ Choose a reasonable sampling time of fuzzy control. 


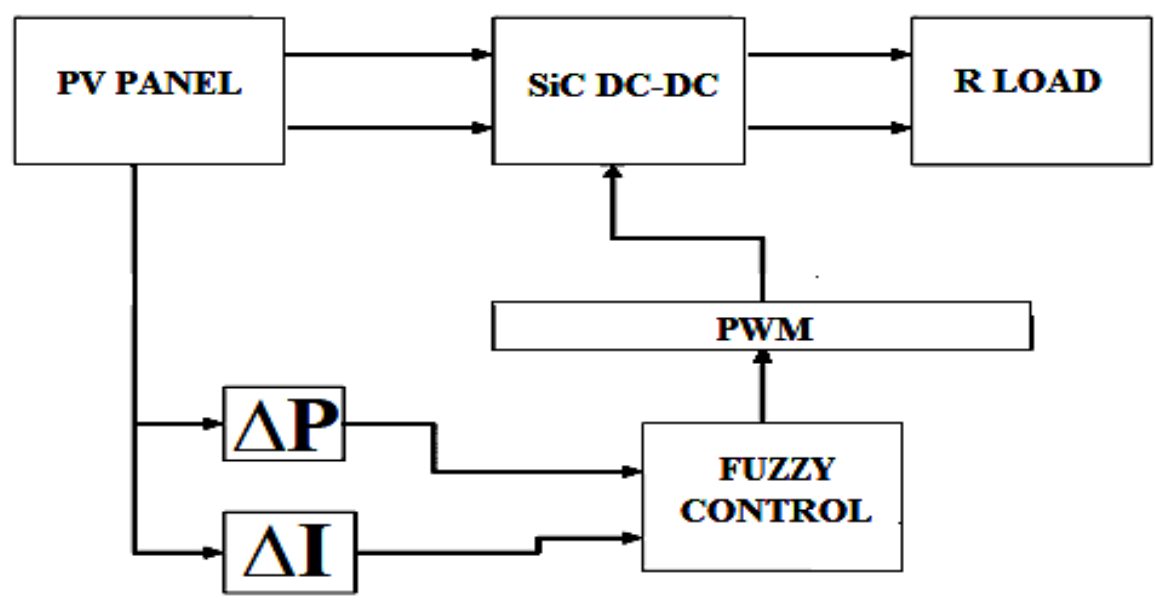

Figure 12.Block diagram of fuzzy logic control based photovoltaic power generation system.

The inputs of the FLC are:

$\Delta P=I(k)-P(k-1)$

$\Delta I=I(k)-I(k-1)$

and the output equation is:

$\Delta D=D(k)-D(k-1) \ldots \ldots(7)$

Where $\Delta \mathrm{P}$ is the $\mathrm{PV}$ array output power change, $\Delta \mathrm{I}$ is the array output current change, and $\Delta \mathrm{D}$ is the boost converter duty cycle change. The variable inputs and outputs are divided into four fuzzy subsets: PB (Positive Big), PS (Positive Small), NB (Negative Big) and NS (Negative Small). Therefore, the fuzzy rule algorithm requires 16 fuzzy control rules; these rules are based on the regulation of hill climbing algorithm, fuzzy rules are shown in Table1. To operate the fuzzy combination, Mamdani's method with Max-Min is used. Figure. 13 shows the FLC based MPPT.

Table I: Fuzzy logic rules

\begin{tabular}{|c|c|c|c|c|}
\hline e/de & NB & NS & PS & PB \\
\hline NB & PB & PB & NB & NB \\
\hline NS & PS & PS & NS & NS \\
\hline PS & NS & NS & PS & PS \\
\hline PB & NB & NB & PB & PB \\
\hline
\end{tabular}

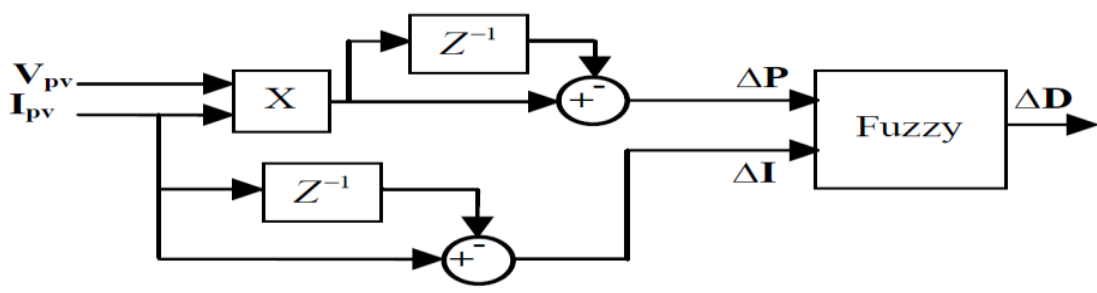


Figure.13. Block diagram of the FLC based MPPT

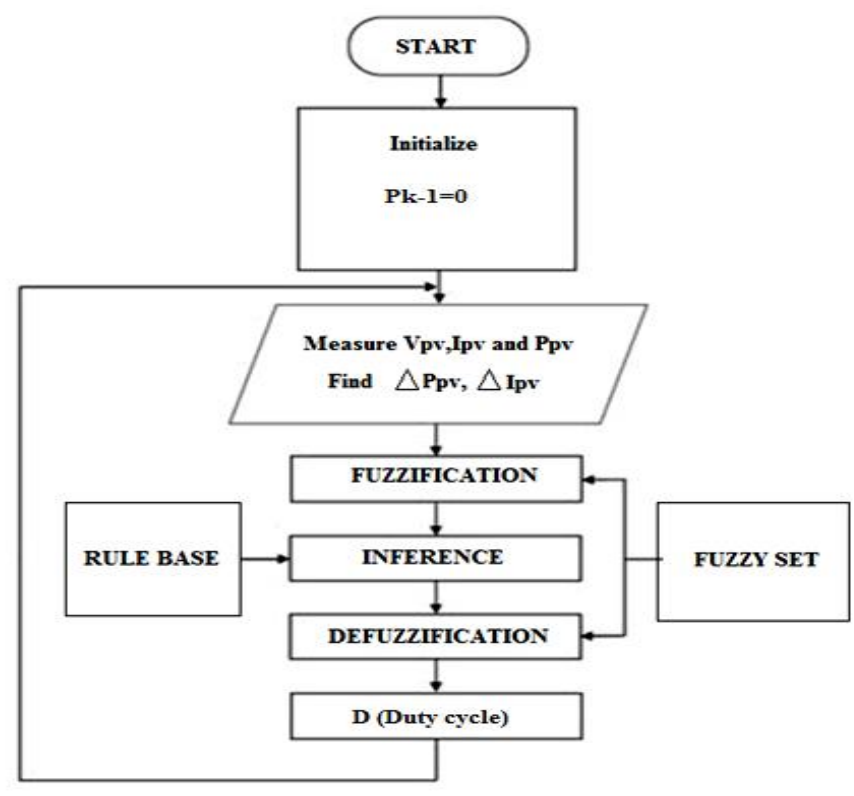

Figure.14. Flow chart of the FLC based MPPT

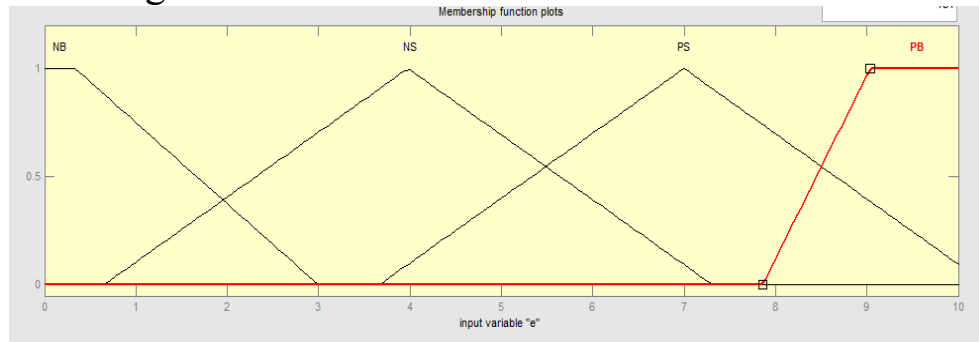

Fig.15. Membership functions: input $\Delta \mathrm{P}$

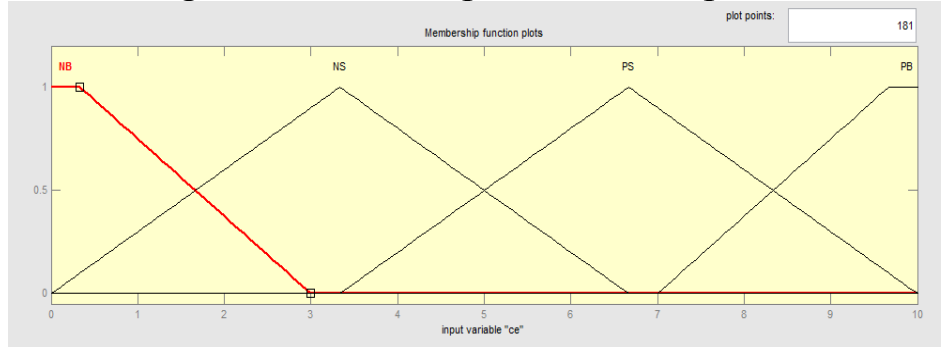

Fig.16. Membership functions: input $\Delta \mathrm{I}$

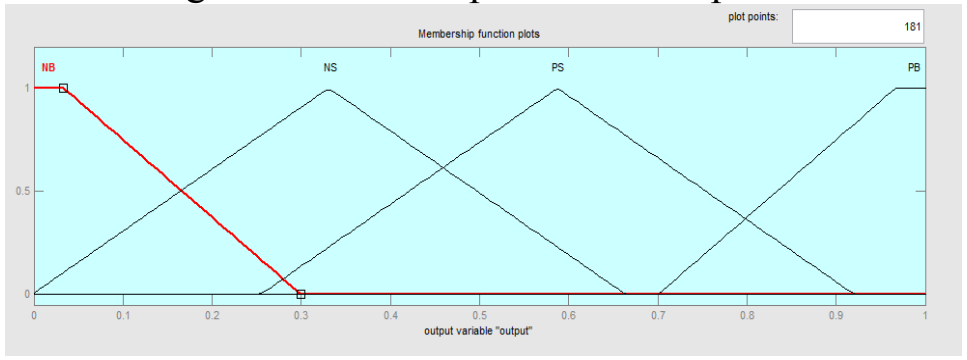


Fig.17. Membership functions: output $\Delta \mathrm{D}$

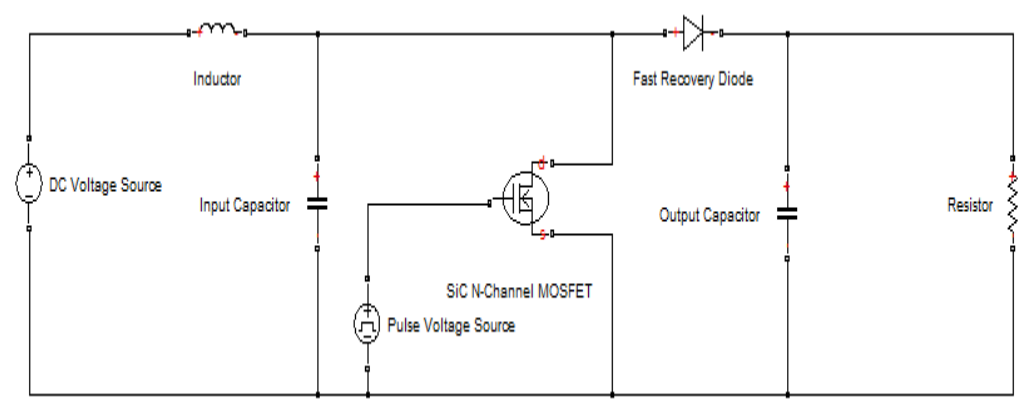

Figure 18: Circuit diagram of boost converter
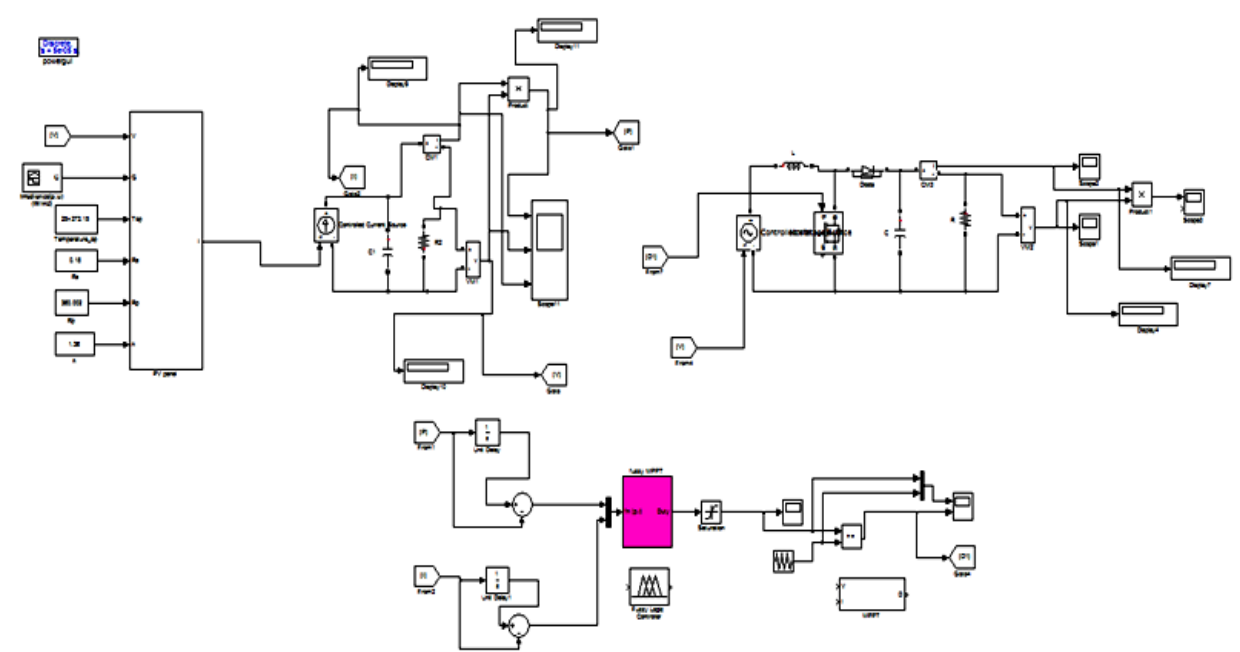

Figure 19: Simulink model of the fuzzy MPPT control of SiC DC - DC boost converter based photovoltaic power generation

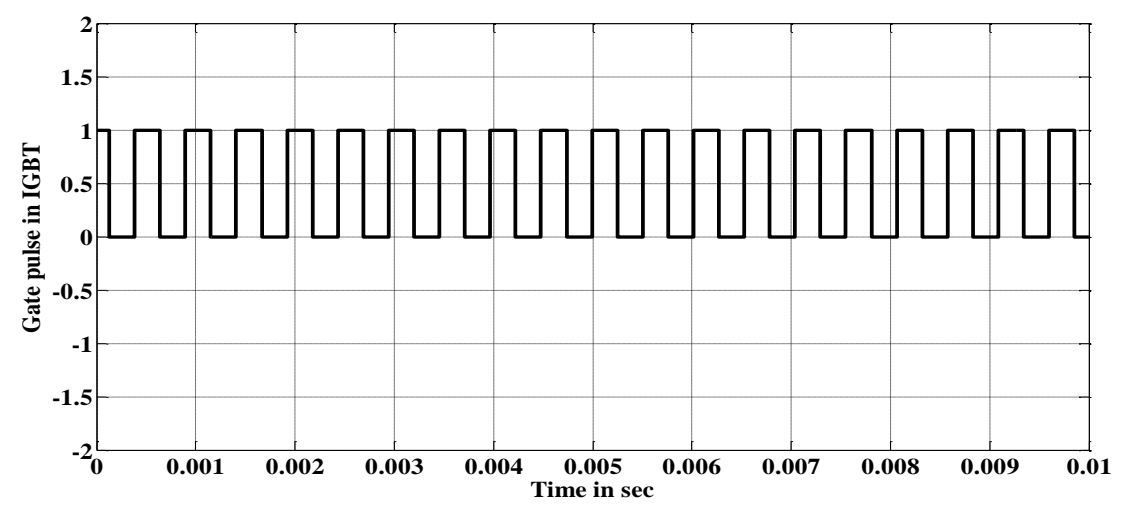

Figure .20: Gate pulse of SiC MOSFET 


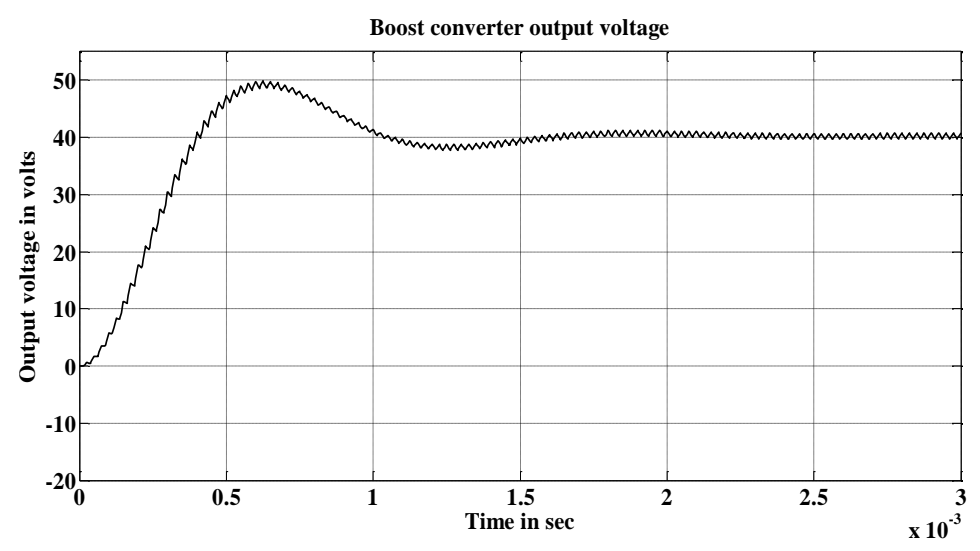

Figure .21: Output voltage of boost converter.

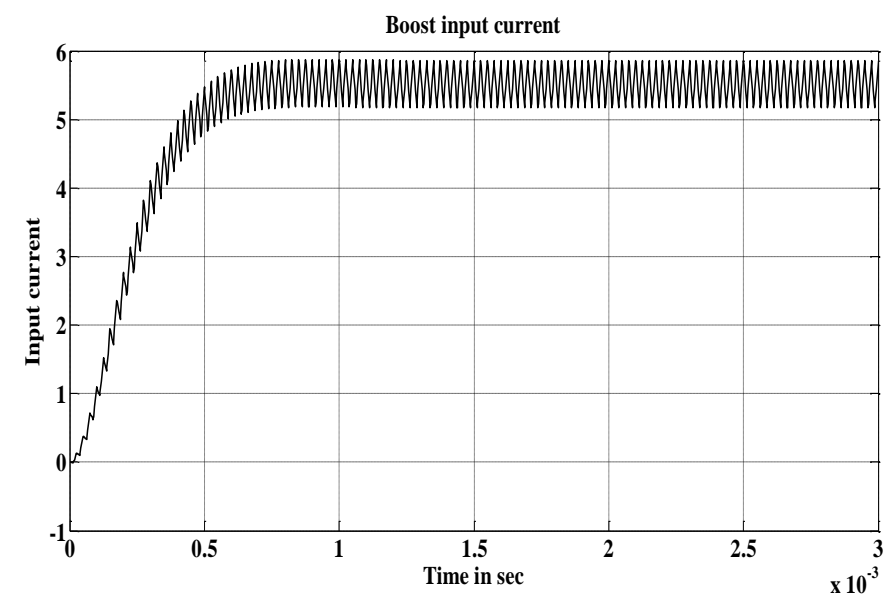

Figure .22: Input current of boost converter

From the behavior of the controller inputs and output, the shapes and fuzzy subset partitions of the membership function of both input and output are shown in Figures.15-17. Flow chart of the FLC based MPPT is shown in Figure.14. The centre of

Where $\Delta \mathrm{D}$ is the fuzzy controller output and Di is the centre of Max-Min composition at the output membership function.

\section{SiC Mosfet Based Boost DC-DC Converter}

A single photovoltaic cell produces voltage of low level. In order to boost up the voltage, a DC-DC boost converter is used. In order to use this DC-DC converter for high voltage and high frequency area algorithm (COA) is used in the defuzzification stage to convert the fuzzy subset duty cycle changes to real numbers.

$$
\Delta D=\frac{\sum_{i}^{n} \mu\left(D_{i}\right) D_{i}}{\sum_{i}^{n} \mu\left(D_{i}\right)}
$$

applications, Choppers are static DC-DC converters for generating variable $\mathrm{DC}$ voltage source from a fixed DC voltage source. It is used to step up the input voltage to a required output voltage without the use of a transformer. Silicon Carbide (SiC) device is most preferred because of larger current carrying capability, higher voltage blocking capability, high operating temperature and less static and dynamic losses than the traditional silicon ( $\mathrm{Si}$ ) power switches [20-22]. The control strategy lies in the manipulation of the duty cycle of the switch which causes the voltage change. The 
circuit diagram of the designed boost converter is shown in Figure.18.

The active switch in the boost converter is a $1200 \mathrm{~V} \mathrm{SiC} \mathrm{MOSFET.} \mathrm{A} \mathrm{fast} \mathrm{recovery} \mathrm{diode}$ is used as the freewheeling diode. The input and output capacitor is selected as $\mathrm{C}_{1}=$ $470 \mu \mathrm{F}$ and $\mathrm{C}_{2}=330 \mu \mathrm{F}, 450 \mathrm{~V}$. The inductance value is $2 \mathrm{mH}, 15 \mathrm{~A}$. The functioning principle of the boost consist to excite the switch (SiC MOSFET) transistor with a duty cycle D produced by the MPPT control, when the switch is closed the inductor $\mathrm{L}$ is loading during $\mathrm{T}(\mathrm{D})$ time, afterwards the switch is opened the inductor supplies the load $\mathrm{R}$ through the diode during (1-D)T. For a DC-DC boost converter, the input-output voltage relationship for continuous conduction mode is given by:

$$
\frac{V_{\mathrm{o}}}{V_{\text {in }}}=\frac{1}{1-D} \ldots \text { (9) }
$$

Where, $D$ is the duty cycle since the duty ratio " $D$ " is between 0 and 1 . Simulink model of the fuzzy MPPT control of SiC
DC- DC boost converter based photovoltaic power generation is shown in Figure.19. The DC- DC boost converter output voltage is about 42 Volts and input current of DCDC boost converter is about 5.5 amps as shown in Figures.21- 22.The gate pulse of $\mathrm{SiC}$ MOSFET switch with $50 \%$ duty cycle is shown in Figure. 20.

\section{Experimental Setup of Photovoltaic Power Generation}

The hardware set-up for fuzzy MPPT control based photovoltaic power generation is shown in Figure.23. In the experimental test conducted on photovoltaic panel with resistive load is shown in Figure.24. Photovoltaic panel specification is shown in table 2.It was observed photovoltaic panel output current and output voltage at various temperatures is shown in Table 3. The P-V and V-I characteristics for a photovoltaic panel are shown in Figure.25.

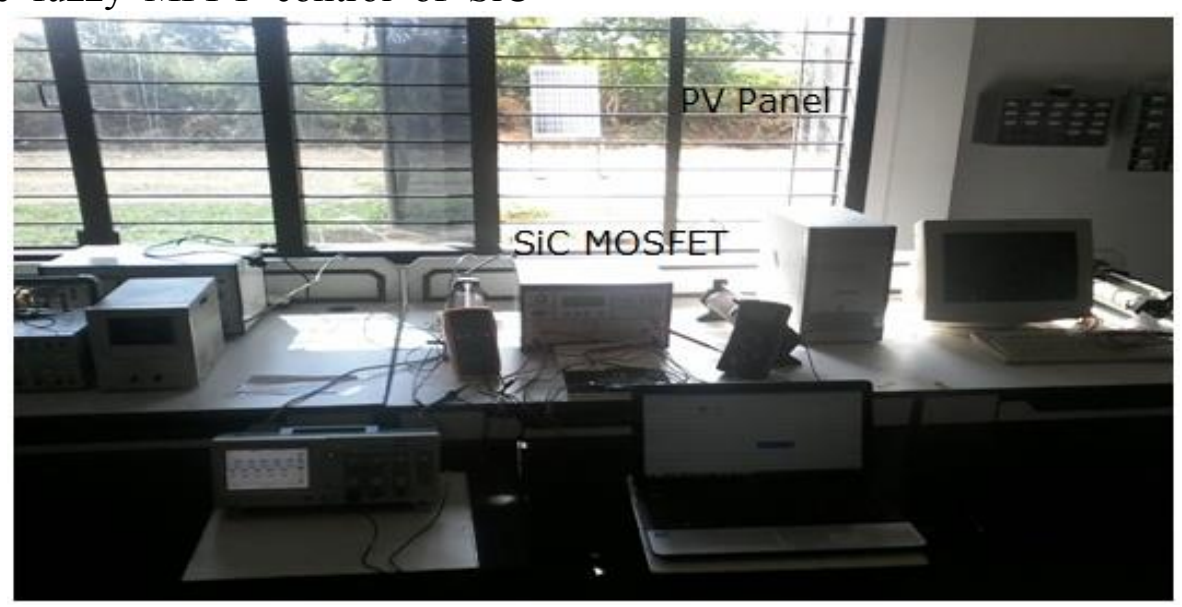

Figure.23.Hardware set-up for fuzzy MPPT control based photovoltaic power generation system 


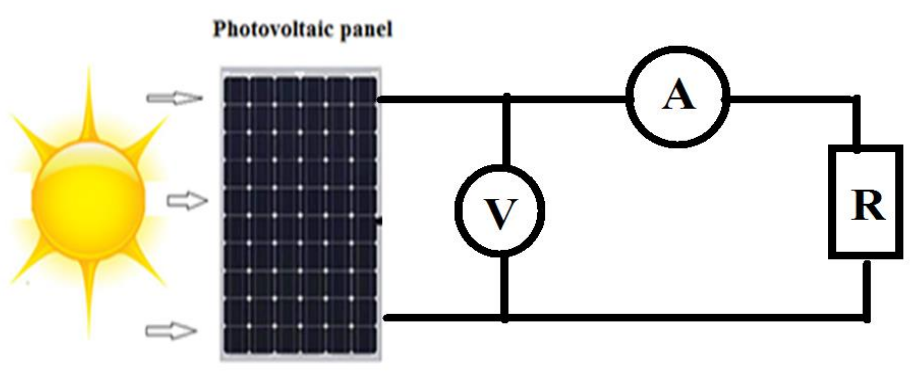

Figure 24.Experimental setup on photovoltaic panel

Table 2. Specification of PV Panel

\begin{tabular}{|c|c|}
\hline $\mathbf{V}_{\text {oc }}$ & $21.16 \mathrm{~V}$ \\
\hline $\mathbf{I}_{\text {sc }}$ & $5.87 \mathrm{~A}$ \\
\hline $\mathbf{P}_{\max }$ & $95.32 \mathrm{~W}$ \\
\hline Insolation W/m & $1000 \mathrm{~W} / \mathrm{m}^{2}$ \\
\hline System efficiency & $76.72 \mathrm{~W}$ \\
\hline
\end{tabular}

Table 3. Voltage and current of PV at different time intervals

\begin{tabular}{|c|c|c|c|}
\hline Time & Voltmeter in volts & Ammeter in amps & Power in Watts \\
\hline $10 \mathrm{am}$ & 19.5 & 5.0 & 98 \\
\hline $11 \mathrm{am}$ & 20 & 5.1 & 102 \\
\hline $12 \mathrm{pm}$ & 20.3 & 5.2 & 103 \\
\hline $1 \mathrm{pm}$ & 20.2 & 5.2 & 103 \\
\hline $2 \mathrm{pm}$ & 20 & 5.1 & 102 \\
\hline $3 \mathrm{pm}$ & 19 & 5.0 & 95 \\
\hline
\end{tabular}

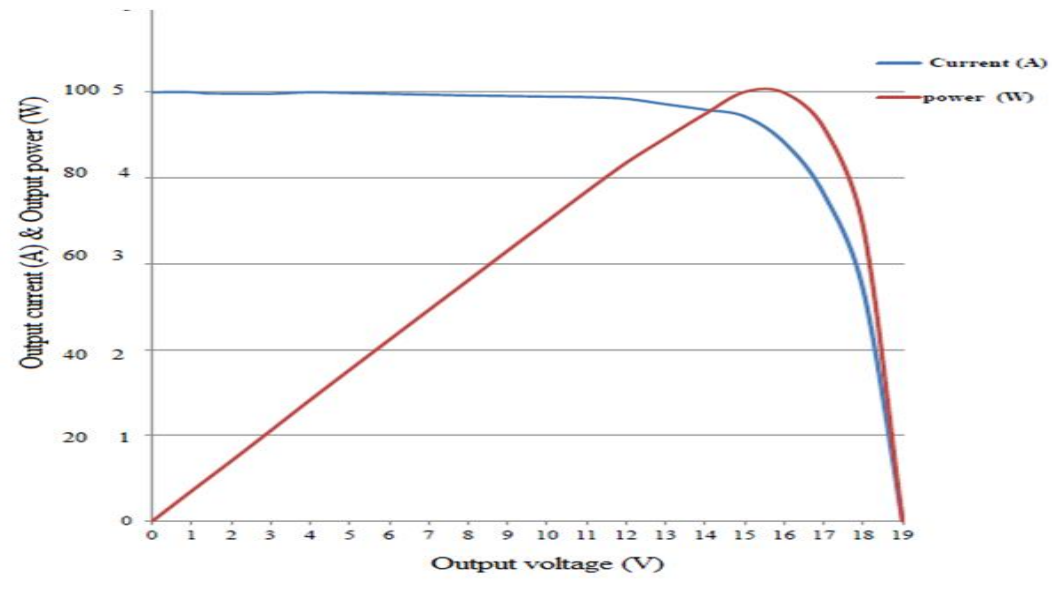

Figure 25: P-V \& V-I characteristics of a photovoltaic panel 


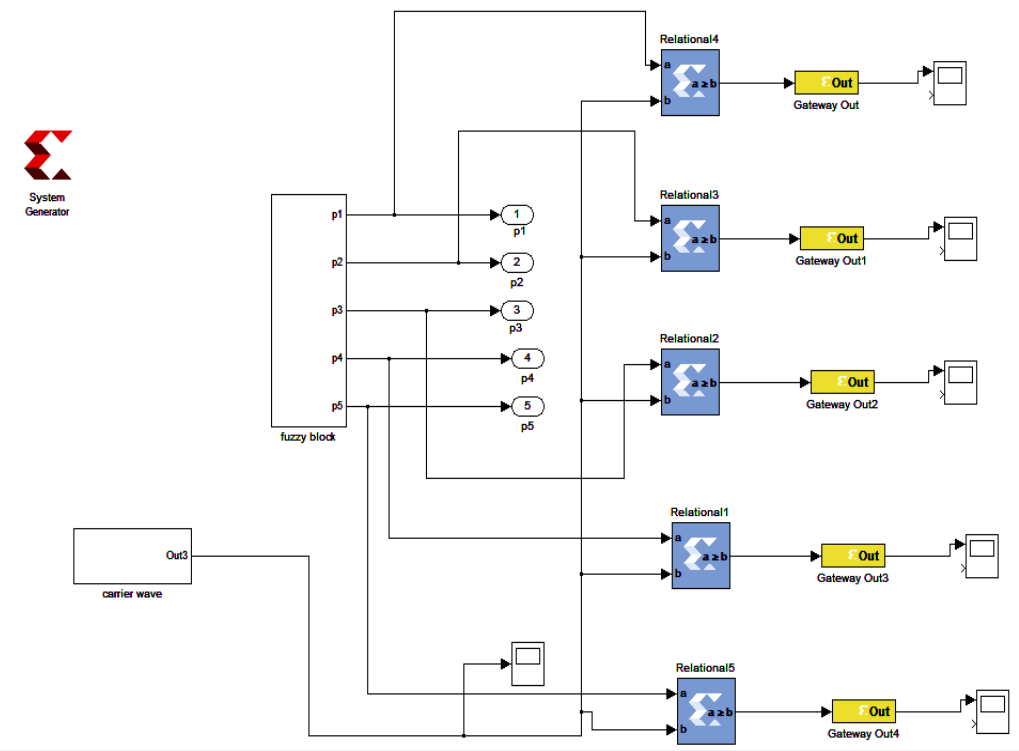

Figure 26: The logic diagram in Xilinx software for the FLC. $50 \%$ duty cycle

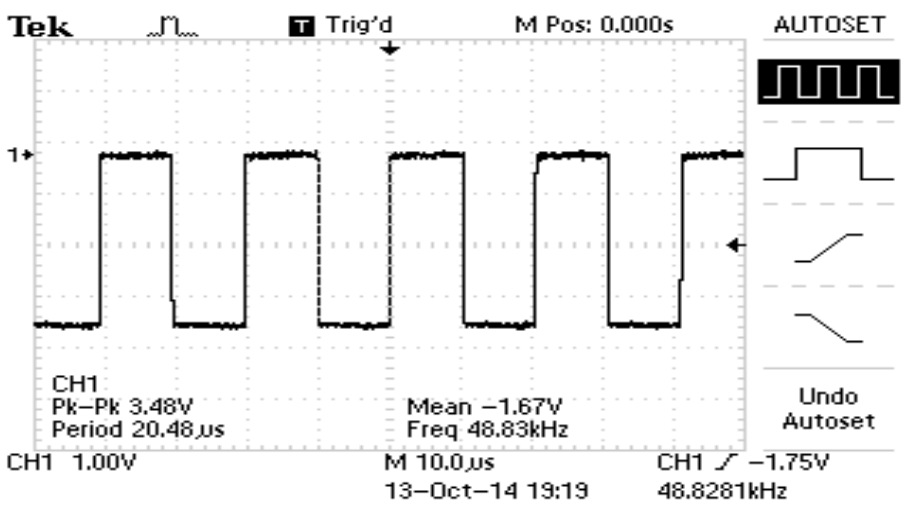

Figure.27. PWM output for 50\% duty ratio

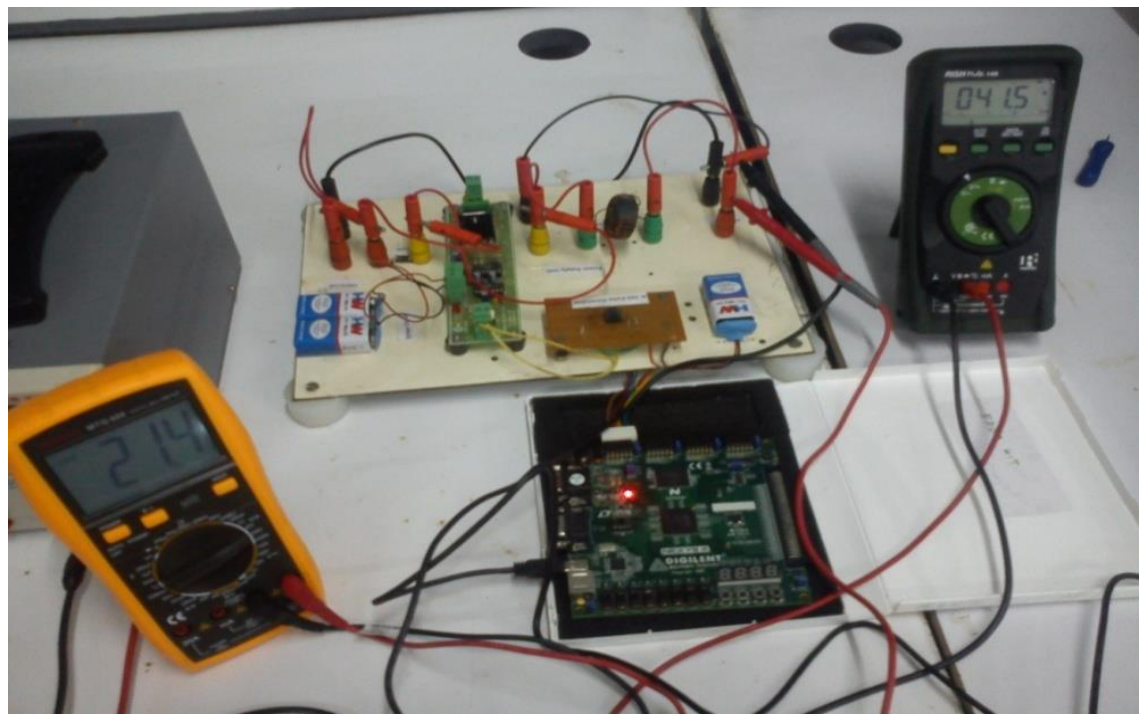


Figure 28.Input and Output voltage of $\mathrm{SiC}$ boost converter using fuzzy MPPT.

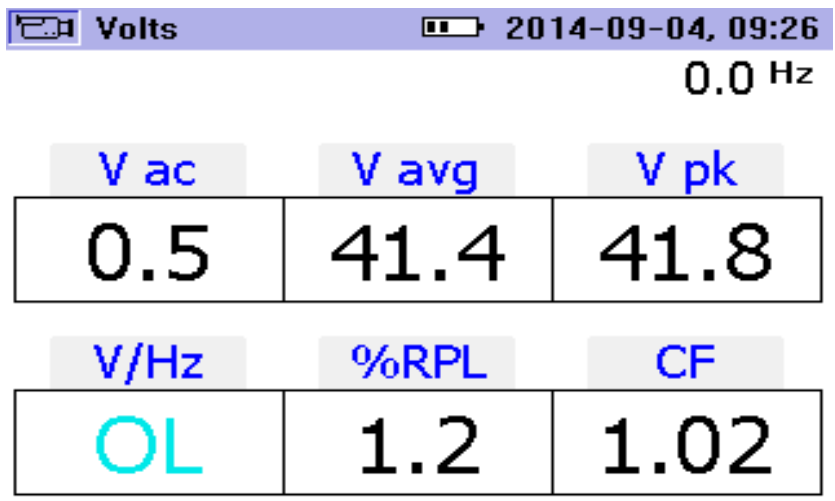

Figure 29. Output voltage ripple of $\mathrm{SiC}$ boost converter for $50 \%$ duty cycle Output voltage ripple of $\mathrm{SiC}$ boost converter is about $1.2 \%$ as shown in Figure.29

Table 4: Experimental result of $\mathrm{SiC}$ and $\mathrm{Si}$ boost converter output voltage ripple for various duty

\begin{tabular}{|c|c|c|c|}
\hline \multicolumn{5}{|c|}{ cycle } \\
S.NO & $\begin{array}{c}\text { Duty } \\
\text { Cycle } \\
\%\end{array}$ & $\begin{array}{c}\mathrm{Si} \\
\text { Output } \\
\text { voltage } \\
\text { ripple } \\
\%\end{array}$ & $\begin{array}{c}\mathrm{SiC} \\
\text { Output } \\
\text { voltage } \\
\text { ripple } \\
\%\end{array}$ \\
\hline 1 & 40 & 4.8 & 1.5 \\
\hline 2 & 50 & 4.1 & 1.2 \\
\hline 3 & 60 & 3.9 & 1.1 \\
\hline 4 & 70 & 3.7 & 0.9 \\
\hline
\end{tabular}

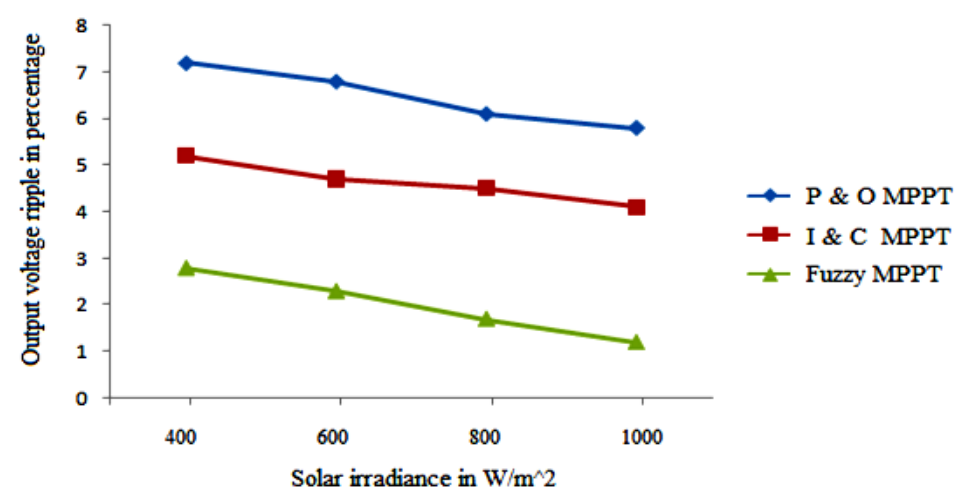

Figure 30. Output voltage ripple Vs Solar irradiance for various MPPT techniques. 


\subsection{Implementing Fuzzy Logic Controller on FPGA}

The fuzzy logic controller for MPPT is implemented on the FPGA board. Then, the DC-to-DC is hooked up and connected to FPGA. Figure.26 shows the logic circuit diagram in Xilinx ISE 14.1 software for the FLC and other components. The inputs of the controller are the error and change in error. $\Delta \mathrm{P}$ is the $\mathrm{PV}$ array output power change, $\Delta \mathrm{I}$ is the array output current change, and $\Delta \mathrm{D}$ is the change in duty cycle. The output of the controller is connected with a PWM module designed on the FPGA. The experimental PWM frequency of the modulating signal is about $50 \mathrm{KHz}$. The output of the PWM is examined using DSO by changing the values of the FLC as shown in Figure. 27.

\section{Results and Discussion}

The hardware for the proposed boost converter is developed using $\mathrm{SiC}$ MOSFET (SCT 2080KE) and fast recovery diode (MUR 3060).The input to the converter is $19.5 \mathrm{~V}$ and an output voltage of $40.9 \mathrm{~V}$ is obtained which is shown in Figure.28. The $\mathrm{SiC}$ MOSFET switches at $50 \mathrm{KHz}$ with 50 $\%$ duty ratio. The output of the converter is examined using DSO by varying the FLC inputs and the change in the duty cycle of the PWM output.. Table 4 shows the comparison of $\mathrm{SiC}$ and $\mathrm{Si}$ boost converter output voltage ripple for various duty cycle and it is found that $\mathrm{SiC}$ based converter provides a reduced output voltage ripple for all the duty ratios. Figure 30 shows the comparison of various MPPT techniques for output voltage ripple calculation. By employing fuzzy based MPP technique, it is observed that the output voltage ripple is reduced compared to other techniques. Therefore, FPGA based fuzzy logic controller with $\mathrm{SiC}$ boost converter is best suited for photovoltaic applications

\section{Conclusion}

This paper has proposed maximum power point tracker using fuzzy control implemented on FPGA Spartan-3E board for PV system. The proposed MPPT controller with SiC boost converter is tested and the results were compared with the conventional system. It is observed that the fuzzy logic control with $\mathrm{SiC}$ boost converter resulted in reduced output voltage ripple of $1.2 \%$ for $50 \%$ duty ratio. The entire system is designed, implemented and tested on a laboratory prototype PV array. The experimental results show the effectiveness and feasibility of the proposed system. Therefore the fuzzy MPPT control with SiC boost converter is more appropriate for photovoltaic power generation system.

References:

[1] Mei Shan Ngan, Chee Wei Tan, "A Study of Maximum Power Point Tracking Algorithms for Stand-alone Photovoltaic Systems," IEEE applied power electronics colloquium, 2011.

[2] V. Salas, E. Oli's, A. Barrado and A. La'zaro, "Review of the maximum power point tracking algorithms for stand-alone photovoltaic systems," Solar Energy Materials \& Solar Cells (2006) 1555-1578.

[3] D. P. Hohm and M. E. Ropp, "Comparative Study of Maximum Power Point Tracking Algorithms," Programme of Photovoltaic Res. Application. 2003; Vol.11:47-62.

[4] S. Lalouni, D. Rekioua, T. Rekioua and E. Matagne, "Fuzzy logic control of stand-alone photovoltaic system with battery storage," Journal of Power Sources Vol.193 (2009) 899907.

[5] Jiyong Li, and Honghua Wang, "Maximum Power Point Tracking of Photovoltaic Generation Based on the Fuzzy Control Method," IEEE SUPERGEN'09, pp. 1-6, 2009. 
[6] Yeong-Chau Kuo, Tsorng-Juu Liang, and Jiann-Fuh Chen, "Novel Maximum-Power-Point-Tracking Controller for Photovoltaic Energy Conversion System," IEEE Transactions on Industrial Electronics, Vol. 48, NO. 3, JUNE 2001.

[7] Yinqing Zoua , Youling Yua, Yu Zhangb and Jicheng Luc, "MPPT Control for PV Generation System Based on an Improved Incremental conductance Algorithm," Procedia Engineering Vol.29 (2012) 105-109.

[8] Ahmad Al-Diab, Constantinos Sourkounis, "Variable Step Size P\&O MPPT Algorithm for PV Systems," 2010, 12th International Conference on Optimization of Electrical and Electronic Equipment, OPTIM 2010.

[9] F. Chekired, C. Larbes, D. Rekioua and F. Haddad, "Implementation of a MPPT fuzzy controller for photovoltaic systems on FPGA circuit," Energy Procedia 6 (2011) 541-549.

[10] F.Bouchafaa, I.Hamzaoui, A.Hadjammar, "Fuzzy Logic Control for the tracking of maximum power point of a PV system," Energy Procedia 6 (2011) 633-642.

[11] G. Balasubramanian, S. Singaravelu, "Fuzzy logic controller for the maximum power point tracking in photovoltaic system," International Journal of Computer Applications (0975 - 8887) Volume 41- No.12, March 2012.

[12] Jun, W., Z. Xiaohu. "10-kV SiC MOSFET-Based Boost Converter," IEEE Transactions on power electronics, 2008.

[13] McNutt, T., A. Hefner, et al. "Silicon Carbide Power MOSFET Model and Parameter Extraction Sequence," IEEE Transactions on power electronics, vol.22, no. 2, pp:217226,MARCH 2007.

[14] Eftichios Koutroulis, Kostas Kalaitzakis and Nicholas C. Voulgaris, "Development of a Microcontroller-Based, Photovoltaic Maximum Power Point Tracking Control System," IEEE transactions on power electronics, Vol. 16, No. 1, January 2001.

[15] Khaehintung N, Wiangtong $\mathrm{T}$, Sirisuk P,'FPGA Implementation of MPPT Using Variable Step-Size P\&O Algorithm for PV Applications", IEEE International Symposium on Communication and Information, IEEE-ISCIT 06,212-215. 2006.

[16] Mekki H., Mellit A., Kalogirou S.A., Messai A. and Furlan, G. FPGABased implementation of a real time photovoltaic module simulator, Progress in Photovoltaics: Research and Application, 2010,115-127.

[17] Messai, A. Mellit, A. Guessoum, and S.A. Kalogirou, "Maximum power point tracking using a GA optimized fuzzy logic controller and its FPGA implementation", Solar energy, 2010.

[18] T. Salmi, M. Bouzguenda, A. Gastli, and A. Masmoudi, "Matlab/Simulink based modelling of solar photovoltaic cell," International Journal of Renewable Energy Research 2012, vol. 2, no. 2, pp. 213-218.

[19] Omura, M. Tsukuda, "High Power Density Converter using SiC-SBD," IEEE Transactions on power electronics ,2007.

[20] J. Wang, T. Zhao, J. Li, A. Q. Huang, R. Callanan, F. Husna, A. Agarwal, "Characterization, Modeling and Application of $10 \mathrm{kV}$ SiC MOSFET," to be published in IEEE Trans. Electron Devices, Aug.2008. 
[21] Shimi Sudha Letha; Tilak Thakur; Jagdish Kumar; Dnyaneshwar Karanjkar; Santanu Chatterji, "Design and Real Time Simulation of Artificial Intelligent Based MPP Tracker for Photo-Voltaic System" Proc. ASME, Volume 6B,Energy,November 14, 2014.

[22] M. Averbukh; Y. Ben-Galim; A. Uhananov ,'Development of a Quick Dynamic Response Maximum Power Point Tracking Algorithm for OffGrid System With Adaptive Switching (On-Off) Control of dc/dc Converter Journal Solar Energy Engineering, 2012.

[23] Kuan-Wei Wu, Mansour Karkoub, Tzu-Sung Wu, "Robust Adaptive Fuzzy Control Design for 3-D Tower Crane with Time Delayed States", pp.26-33, Volume 2, 2020, International Journal of
Electrical Engineering and Computer Science (EEACS).

[24] Hitesh Shah, M.Gopal, "A Reinforcement Learning Algorithm With Evolving Fuzzy Neural Networks", pp.68-72, Volume 2, 2020, International Journal of Electrical Engineering and Computer Science (EEACS).

[25] Mohammed Faisal, Khalid Al-Mutib, Ramdane Hedjar, Hassan Mathkour, Mansour Alsulaiman, Ebrahim Mattar, "Multi Modules Fuzzy Logic for Mobile Robots Navigation and Obstacle Avoidance in Unknown Indoor Dynamic Environment", pp.59-67, Volume 2, 2020, International Journal of Electrical Engineering and Computer Science (EEACS)

\section{Creative Commons Attribution License 4.0 (Attribution 4.0 International, CC BY 4.0)}

This article is published under the terms of the Creative Commons Attribution License 4.0

https://creativecommons.org/licenses/by/4.0/deed.en US 